approach the promising yet immature field of stem cells. It also shows the importance of the FDA's regulatory role. Yet, as described on page 166, that role has been questioned by a Texas stem-cell-therapy company. The firm, Celltex Therapeutics in Houston, has demonized the agency to its patients, some of whom seethe at what they see as government intrusion.

The situation with Celltex is different from the Sapse case - the Texas company believes in its treatments, its doctors are real and its stem-cell manufacturing was registered with the FDA, for example. But the quality of the stem cells that Celltex used was not ensured, and follow-up on patients seems not to have been rigorous.

Celltex frames its dispute with the FDA as a conflict between a brave company that wants to offer cutting-edge medicine to desperate patients and a tyrannical bureaucratic ogre that is holding it back. But some of the facts don't fit that simple narrative.

Patient care is about more than intervention. It demands top-quality processing facilities, systematic administration of therapies and meticulous follow-up, so that informed decisions can be made for current and future patients. If Celltex wanted to be the standard-bearer for a new form of cell-based therapy, if it wanted to have a showdown with a federal agency by demonstrating that regulations stand in the way of scientific progress and patient health, it should have produced the best evidence of safety and efficacy that it could muster. That would have stimulated an interesting and constructive debate and created real pressure for change at the FDA.

Certainly, there is room for the FDA to improve the regulation of stem cells. The large clinical trials that the rules currently demand are so expensive that many researchers and biotechnology companies cannot afford to conduct them. To ease that problem, the agency could explore expanding its 'compassionate use' clause, which allows individual patients to pay for drugs that are being used in FDAapproved trials. Alternative funding mechanisms, perhaps involving national insurance programmes, could be used to help offset the costs to patients and to those who perform the trials.

To enact such a change, the FDA would probably need more money to ensure that companies are serious about developing medicines and not simply seeking a loophole to increase profit. Increased FDA funding could also enable the agency to waive or reduce fees paid by the
"Patients are ready to take risks and clinical researchers are ready to do studies." (usually small) biotechnology companies that develop the treatments. Organizations including the Alliance for Regenerative Medicine in Washington DC have been working with the FDA to create a regulatory environment more conducive to the development of stem cells.

More broadly, there has been a boom in people going abroad to receive stem-cell treatments. The World Health Organization (WHO) has taken a stand by issuing guidelines on how to regulate cell transplants. National authorities could actively engage with the WHO to ensure that those guidelines are effective.

All involved want to speed up the introduction of stem cells into the clinic. Patients are ready to take risks and clinical researchers are ready to do studies. Funding bodies should step up with money to help.

The matter is urgent. After the FDA turned up the heat, Sapse went to Mexico for three years before his arrest in 2010. Celltex is moving there now. The longer it takes to develop a workable and affordable system in nations such as the United States, the more patients will travel for treatment to countries where there are even more unknowns.

\section{Damage control}

\section{Planning for extreme events must incorporate not just infrastructure but societal preparedness.}

W hen officials in New York City began to piece together how Superstorm Sandy had managed to flood the subway last October, they found that the storm had driven a bundle of lumber from a construction site right through a plywood barrier built around one of the entrances to the South Ferry subway station. It was a seemingly random act of violence, but in reality, the barriers probably never stood a chance. With a standing-water height of up to 1.5 metres at Battery Park on Manhattan's southernmost tip, the rising tide skirted a second plywood blockade and poured over a waist-high concrete wall at another entrance.

Preparing for hurricanes is hard. But the fact that core infrastructure in a global metropolis such as New York was protected by plywood should trigger alarms. South Ferry is a reminder of just how illprepared New York was for a storm of this magnitude - and it underscores the scale of the challenge ahead.

It wasn't supposed to be this way. New York City has engaged scientists while working to reduce emissions and prepare for a warmer world. In 2008, Mayor Michael Bloomberg created the New York City Panel on Climate Change, and in August the city council gave the panel a permanent place in its long-term planning process. PlaNYC, a planning document that offers a vision of what the city will look like in 2030 , includes a comprehensive chapter on climate change. But none of this prepared the city for Sandy. Nor could it have - the surge that Sandy brought ashore was off the charts.

Legions of scientists are now assessing what happened and projecting future risks. The latest, and perhaps best, estimate, based on models by researchers at Princeton University in New Jersey and the Massachusetts Institute of Technology in Cambridge, is that the storm surge at Battery Park was a 1-in-500-year event. But the size of a surge is not the only measure of a dangerous storm, nor is Battery Park the only location that matters. Scientists also know that the baseline is changing with the climate. All of which leaves the city, its residents and businesses in the unenviable position of rebuilding in the face of an uncertain future.

As this process unfolds, several lessons can be learned from Sandy (see page 162). In many places, premises erected under newer building codes survived the storm with only limited damage at ground level. A new generation of waterfront parks and developments also weathered the storm quite well, showing that there are ways to manage the risks of occasional flooding. But given the predicted sea-level rise and the likelihood of more powerful storms in the future, a more comprehensive strategy is clearly needed.

Some positive signs have emerged. The Federal Emergency Management Agency is updating the city's flood maps, and the city has announced steps to strengthen its building codes. As directed by Congress last year, the agency will also be incorporating long-term climate projections, including for sea-level rise, into its rate structure for the federal flood insurance programme. Until now, the programme has served as a government subsidy for risky coastal development so risky that private insurance companies refused to enter the market.

One of the big questions facing the region is whether to spend billions of dollars on a storm-surge barrier. Scientists and engineers should clearly include a barrier in their analysis, but a surge is just one of many threats posed by many kinds of storm. Moreover, how fast New York bounces back will depend not only on damage to infrastructure $\rightarrow$ NATURE.COM To comment online, click on Editorials at: go.nature.com/xhunqu but also on the strength of social networks and the general health of the communities affected. Farther afield, as sea levels rise, coastal cities will have little choice but to learn to live with more water than they are used to today. 